\title{
Phylogenetic History of Phytophthora cryptogea and $P$. drechsleri Isolates from Floriculture Crops in North Carolina Greenhouses
}

\author{
H. A. Olson, I. Carbone, and D. M. Benson
}

First, second, and third authors: Department of Plant Pathology, North Carolina State University, Raleigh 27695.

Current address of first author: Virginia Tech, Hampton Roads AREC, Virginia Beach 23455.

Accepted for publication 14 June 2011.

\section{ABSTRACT}

Olson, H. A., Carbone, I., and Benson, D. M. 2011. Phylogenetic history of Phytophthora cryptogea and P. drechsleri isolates from floriculture crops in North Carolina greenhouses. Phytopathology 101:1373-1384.

The evolutionary history of Phytophthora cryptogea and P. drechsleri isolates previously collected from floriculture crops in North Carolina commercial greenhouses was explored with coalescent- and parsimonybased analyses. Initially, 68 isolates representing 13 location-host groups were sequenced at multiple loci. Sequences of all isolates within a group were identical. A subset of isolates were selected, cloned to resolve heterozygous sites, and analyzed with SNAP Workbench. The internal transcribed spacer (ITS) region of the ribosomal DNA and cytochrome oxidase II gene genealogies were congruent and indicated that $P$. cryptogea and $P$. drechsleri are sister species diverged from a common ancestor with no evidence of gene flow. In contrast, genealogies inferred from $\beta$-tubulin $(\beta$-tub) and translation elongation factor $1 \alpha(E F-1 \alpha)$ genes were in conflict with these loci. Coalescent analysis based on a nonrecombining partition in $\beta$-tub and $E F-1 \alpha$ showed an initial (older) split between $P$. cryptogea and $P$. drechsleri, with a later (recent) event separating the remaining $P$. cryptogea haplotypes from $P$. drechsleri. A parsimony-based minimal ancestral recombination graph inferred recombination between $P$. cryptogea and $P$. drechsleri isolates in the ITS region and $\beta$-tub, suggesting genetic exchange between species. Also, putative recombination between $\mathrm{A} 1$ and $\mathrm{A} 2$ mating types of $P$. cryptogea suggests that sexual reproduction has occurred in the history of these P. cryptogea isolates.
Multiple species of Phytophthora are known to impact floriculture production, including Phytophthora cryptogea and $P$. drechsleri. Since the initial work with $P$. cryptogea on ornamentals by Tompkins et al. in the 1930s $(45,46)$, this species has been reported on $>40$ floriculture plant species (13). Similarly, $P$. drechsleri has been reported on $>25$ floriculture plant species (14), including multiple hosts which overlap with $P$. cryptogea. $P$. cryptogea was first described by Pethybridge and Lafferty in 1919 with an isolate causing foot rot of tomato in Ireland (40) and, $\approx 10$ years later, Tucker described $P$. drechsleri from an isolate of Phytophthora that caused rot of potato in Idaho (47). Tucker used growth at $35^{\circ} \mathrm{C}$ as a physiological characteristic to distinguish $P$. drechsleri (growth at $35^{\circ} \mathrm{C}$ ) from $P$. cryptogea (no growth at $35^{\circ} \mathrm{C}$ ). Because of highly overlapping morphological characteristics, differentiating $P$. cryptogea and $P$. drechsleri is considered one of the most difficult taxonomic problems in the genus Phytophthora (12). Several research groups have proposed merging the two species because of these morphological identification difficulties $(8,17)$, whereas others believe the species status of each is supported based on the growth at $35^{\circ} \mathrm{C}(22,23)$.

The development of tools to analyze DNA sequence variation has allowed researchers to begin to discern the genetic relatedness of Phytophthora spp. This is particularly useful where morphological and biological characters are ambiguous. Phylogenetic analysis of the internal transcribed spacer (ITS) region of the ribosomal DNA (rDNA) of species of Phytophthora placed $P$.

Corresponding author: H. A. Olson; E-mail address: heather.a.olson@gmail.com

*The $e$-Xtra logo stands for "electronic extra" and indicates that the online version contains three supplemental figures.

doi:10.1094/PHYTO-11-10-0302

(c) 2011 The American Phytopathological Society cryptogea and $P$. drechsleri in clade 8a and supported their species status (9). Similarly, Martin and Tooley (33) utilized the cytochrome oxidase I and II regions of the mitochondrial DNA to infer that $P$. cryptogea and $P$. drechsleri were distinct but closely related species. More recent multilocus phylogenetic gene trees support the inferences from these original single-locus studies $(3,28,42)$. For these studies, one or two isolates of $P$. cryptogea and $P$. drechsleri were used to represent the species. Recently, Mostowfizadeh-Ghalamfarsa et al. (35) evaluated a worldwide collection of isolates of $P$. cryptogea and $P$. drechsleri and found that $P$. cryptogea and $P$. drechsleri are distinct species and are genetically variable.

During a 2007-2008 survey of commercial greenhouse facilities in North Carolina, P. cryptogea was collected from Evolvulus glomeratus (blue daze), Senecio cineraria (dusty miller), Gerbera jamesonii (gerbera daisy), and Verbena $\times$ hybrida (verbena) at five greenhouse locations, and $P$. drechsleri was isolated from Fuchsia $\times$ hybrida (fuchsia) and gerbera daisy at two locations (37). During a previous survey in North Carolina, P. drechsleri was collected from gerbera daisy and dusty miller at two locations (26). In both surveys, all isolates of $P$. drechsleri exhibited a high level of resistance to mefenoxam, the active ingredient of a fungicide commonly used in the management of Phytophthora spp. in floriculture production $(26,37)$. In contrast, all isolates of $P$. cryptogea were sensitive to mefenoxam.

The objective of this study was to characterize the ancestral relationships and evolutionary processes of the isolates of $P$. cryptogea and $P$. drechsleri collected from floriculture crops in North Carolina commercial greenhouse facilities. Specifically, coalescent- and parsimony-based methods were used to explore the evolutionary history of $P$. cryptogea and $P$. drechsleri for evidence of gene flow, which could have important management implications for these species in the floriculture industry. 


\section{MATERIALS AND METHODS}

Isolates and DNA extraction. Isolates of $P$. cryptogea and $P$. drechsleri were obtained from commercial greenhouse facilities in North Carolina during surveys conducted in 2001-2002 (26) and 2007-2008 (37) (Table 1). These isolates previously had been characterized for mating type, mefenoxam sensitivity, and growth at $35^{\circ} \mathrm{C}(26,37)$. In addition, reference isolates of $P$. drechsleri

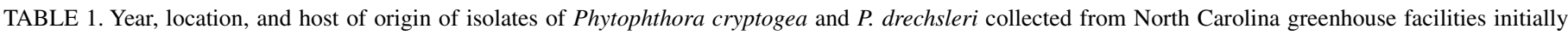
sequenced

\begin{tabular}{|c|c|c|c|c|}
\hline Isolate & Species & Year & Location & Host scientific name \\
\hline P1088/ATCC46721 ${ }^{\mathrm{a}}$ & P. cryptogea & 1935 & California & Callistephus chinensis \\
\hline NC108 & P. cryptogea & 2007 & B & Gerbera jamesonii \\
\hline NC110 & P. cryptogea & 2007 & B & G. jamesonii \\
\hline NC208 & P. cryptogea & 2008 & $\mathrm{C}$ & Evolvulus glomeratus \\
\hline NC594 & P. cryptogea & 2008 & $\mathrm{E}$ & G. jamesonii \\
\hline NC597 & P. cryptogea & 2008 & $\mathrm{E}$ & G. jamesonii \\
\hline NC1105 & P. cryptogea & 2008 & $\mathrm{I}$ & Verbena $\times$ hybrida \\
\hline NC1145 & P. cryptogea & 2008 & $\mathrm{~J}$ & Senecio cineraria \\
\hline NC1146 & P. cryptogea & 2008 & $\mathrm{~J}$ & S. cineraria \\
\hline NC1147 & P. cryptogea & 2008 & $\mathrm{~J}$ & S. cineraria \\
\hline NC1148 & P. cryptogea & 2008 & $\mathrm{~J}$ & S. cineraria \\
\hline NC1149 & P. cryptogea & 2008 & $\mathrm{~J}$ & S. cineraria \\
\hline NC1150 & P. cryptogea & 2008 & $\mathrm{~J}$ & S. cineraria \\
\hline $\mathrm{NC} 1151$ & P. cryptogea & 2008 & $\mathrm{~J}$ & S. cineraria \\
\hline NC1152 & P. cryptogea & 2008 & $\mathrm{~J}$ & S. cineraria \\
\hline NC1153 & P. cryptogea & 2008 & $\mathrm{~J}$ & S. cineraria \\
\hline P1087/ATCC46724 ${ }^{\mathrm{a}}$ & P. drechsleri & 1936 & California & Beta vulgaris \\
\hline $\mathrm{NC} 83$ & P. drechsleri & 2007 & $\mathrm{~B}$ & G. jamesonii \\
\hline NC86 & P. drechsleri & 2007 & $\mathrm{~B}$ & G. jamesonii \\
\hline NC88 & P. drechsleri & 2007 & $\mathrm{~B}$ & G. jamesonii \\
\hline NC91 & P. drechsleri & 2007 & $\mathrm{~B}$ & G. jamesonii \\
\hline NC95 & P. drechsleri & 2007 & B & G. jamesonii \\
\hline NC96 & P. drechsleri & 2007 & $\mathrm{~B}$ & G. jamesonii \\
\hline NC99 & P. drechsleri & 2007 & $\mathrm{~B}$ & G. jamesonii \\
\hline NC103 & P. drechsleri & 2007 & $\mathrm{~B}$ & G. jamesonii \\
\hline NC109 & P. drechsleri & 2007 & B & G. jamesonii \\
\hline NC114 & P. drechsleri & 2007 & B & G. jamesonii \\
\hline NC947 & P. drechsleri & 2008 & G & G. jamesonii \\
\hline NC948 & P. drechsleri & 2008 & G & G. jamesonii \\
\hline NC955 & P. drechsleri & 2008 & G & G. jamesonii \\
\hline NC957 & P. drechsleri & 2008 & $\mathrm{G}$ & Fuchsia $\times$ hybrida \\
\hline NC961 & P. drechsleri & 2008 & G & Fuchsia $\times$ hybrida \\
\hline NC966 & P. drechsleri & 2008 & G & G. jamesonii \\
\hline CRGB1 & P. drechsleri & 2002 & $\mathrm{~B}$ & G. jamesonii \\
\hline CRGB6 & P. drechsleri & 2002 & $\mathrm{~B}$ & G. jamesonii \\
\hline CRGB8 & P. drechsleri & 2002 & $\mathrm{~B}$ & G. jamesonii \\
\hline CRGB11 & P. drechsleri & 2002 & $\mathrm{~B}$ & G. jamesonii \\
\hline CRGB42 & P. drechsleri & 2002 & $\mathrm{~B}$ & G. jamesonii \\
\hline CRGB51 & P. drechsleri & 2002 & $\mathrm{~B}$ & G. jamesonii \\
\hline FDM2 & P. drechsleri & 2001 & A & S. cineraria \\
\hline FDM4 & P. drechsleri & 2001 & A & S. cineraria \\
\hline FDM5 & P. drechsleri & 2001 & A & S. cineraria \\
\hline FDM6 & P. drechsleri & 2001 & $\mathrm{~A}$ & S. cineraria \\
\hline FDM8 & P. drechsleri & 2001 & A & S. cineraria \\
\hline FDM10 & P. drechsleri & 2001 & A & S. cineraria \\
\hline FDM11 & P. drechsleri & 2001 & A & S. cineraria \\
\hline FDM13 & P. drechsleri & 2001 & A & S. cineraria \\
\hline FDM14 & P. drechsleri & 2001 & A & S. cineraria \\
\hline FDM15 & P. drechsleri & 2001 & A & S. cineraria \\
\hline FWDM1 & P. drechsleri & 2002 & A & S. cineraria \\
\hline FWMD16 & P. drechsleri & 2002 & A & S. cineraria \\
\hline FWDM18 & P. drechsleri & 2002 & A & S. cineraria \\
\hline FWDM19 & P. drechsleri & 2002 & A & S. cineraria \\
\hline FWDM20 & P. drechsleri & 2002 & A & S. cineraria \\
\hline FWDM23 & P. drechsleri & 2002 & A & S. cineraria \\
\hline FWDM24 & P. drechsleri & 2002 & A & S. cineraria \\
\hline FWDM25 & P. drechsleri & 2002 & A & S. cineraria \\
\hline FWDM26 & P. drechsleri & 2002 & A & S. cineraria \\
\hline FWGB1 & P. drechsleri & 2002 & A & G. jamesonii \\
\hline FWGB2 & P. drechsleri & 2002 & A & G. jamesonii \\
\hline FWGB3 & P. drechsleri & 2002 & A & G. jamesonii \\
\hline FWGB4 & P. drechsleri & 2002 & A & G. jamesonii \\
\hline FWGB5 & P. drechsleri & 2002 & A & G. jamesonii \\
\hline FWGB6 & P. drechsleri & 2002 & A & G. jamesonii \\
\hline FWGB7 & P. drechsleri & 2002 & A & G. jamesonii \\
\hline FWGB9 & P. drechsleri & 2002 & A & G. jamesonii \\
\hline FWGB10 & P. drechsleri & 2002 & A & G. jamesonii \\
\hline FWGB11 & P. drechsleri & 2002 & A & G. jamesonii \\
\hline
\end{tabular}

a Isolate obtained from World Oomycete Genetic Resource Collection; ATCC = American Type Culture Collection (44,46). 
and $P$. cryptogea were obtained from the World Oomycete Genetic Resource Collection (Table 1). For P. drechsleri, isolate P1087 (ATCC46724) isolated from sugar beet by Tompkins et al. (44) was chosen because Mostowfizadeh-Ghalamfarsa et al. (35) used it as the type isolate for $P$. drechsleri, and P. cryptogea isolate P1088 (ATCC46721) collected from China aster by Tompkins et al. (46) was chosen for reference because Blair et al. (3) used P1088 to represent $P$. cryptogea in a multilocus Phytophthora phylogeny. Each isolate was grown in pea broth for 5 to 7 days at 20 to $25^{\circ} \mathrm{C}$. Three 7 -mm agar disks of an isolate were transferred to $25 \mathrm{ml}$ of pea broth in a $250-\mathrm{ml}$ flask. Pea broth was prepared by autoclaving $120 \mathrm{~g}$ of frozen green peas in $500 \mathrm{ml}$ of deionized water for $5 \mathrm{~min}$. After cooling, the solution was filtered through several layers of cheesecloth to remove the peas. Deionized water was added to bring the total volume to 1 liter. Aliquots $(25-\mathrm{ml})$ of pea broth were placed into $250-\mathrm{ml}$ flasks, which were subsequently autoclaved for $30 \mathrm{~min}$. Mycelia mats were harvested by vacuum filtration, placed in a $1.5-\mathrm{ml}$ microcentrifuge tube, and stored at $-20^{\circ} \mathrm{C}$.

DNA was extracted from mycelia with the PUREGENE DNA Isolation Kit for 10 to $20 \mathrm{mg}$ of fungal tissue (Qiagen, Valencia, CA) with a protocol optimized for Phytophthora spp. Frozen mycelial tissue was ground in a $1.5-\mathrm{ml}$ microcentrifuge tube using a disposable pestle for 15 to $20 \mathrm{~s}$. To lyse cells, $600 \mu \mathrm{l}$ of the cell lysis solution was added, and the cells were ground with the pestle. Once the solution was homogenized, $3 \mu$ of Proteinase K was added and tubes were vortexed on high for $20 \mathrm{~s}$. Samples were incubated at $55^{\circ} \mathrm{C}$ overnight. Tubes were centrifuged at $5,000 \times g$ for $5 \mathrm{~min}$. The resulting supernatant was pipetted into new $1.5-\mathrm{ml}$ microcentrifuge tubes, and $3 \mu \mathrm{l}$ of RNase A solution was added. Samples were incubated at $37^{\circ} \mathrm{C}$ for $25 \mathrm{~min}$ and then cooled to 20 to $25^{\circ} \mathrm{C}$. To remove proteins, $200 \mu \mathrm{l}$ of protein precipitation solution were added, and samples were vortexed on high speed for $20 \mathrm{~s}$. Tubes were incubated on ice for $20 \mathrm{~min}$. The samples were centrifuged at $18,000 \times g$ for $3 \mathrm{~min}$ and then returned to ice. The clear portion of the supernatant was trans- ferred to new $1.5-\mathrm{ml}$ microcentrifuge tubes containing $600 \mu \mathrm{l}$ of $100 \%$ isopropanol. The tubes were gently inverted 30 times to mix and, subsequently, centrifuged at $18,000 \times g$ for $3 \mathrm{~min}$. The supernatant was discarded, and the resulting DNA pellets were retained in the microcentrifuge tubes. To wash the DNA, $400 \mu \mathrm{l}$ of $70 \%$ ethanol was pipetted down the side of the tubes. The samples were centrifuged at $18,000 \times g$ for $3 \mathrm{~min}$. The ethanol was poured off, and the DNA pellets were retained in the microcentrifuge tubes. Samples were incubated at $55^{\circ} \mathrm{C}$ to evaporate any remaining ethanol. The DNA was rehydrated by adding $50 \mu \mathrm{l}$ of nuclease-free water and incubating at $55^{\circ} \mathrm{C}$ for $1 \mathrm{~h}$. Extracted DNA was stored at $-20^{\circ} \mathrm{C}$.

Polymerase chain reaction and DNA sequencing. Four loci were chosen for genetic characterization: the ITS region (ITS1, $5.8 \mathrm{~S}$, and ITS2) of the rDNA; the translation elongation factor $1 \alpha$ gene $(E F-1 \alpha)$; the $\beta$-tubulin gene $(\beta$-tub); and the cytochrome oxidase II and internal spacer (coxII) region of the mitochondrial DNA. The polymerase chain reaction (PCR) primers, reaction mixtures, and cycling conditions are summarized in Table 2. Amplification products were confirmed by gel electrophoresis (1\% agarose; $95 \mathrm{~V}$ for $75 \mathrm{~min}$ ), purified with the Wizard SV Gel and PCR Clean-up System (Promega Corp., Madison, WI), sequenced using the BigDye Terminator 3.1 cycle sequencing kit (Applied Biosystems, Foster City, CA), and analyzed on an Applied Biosystems 3730xl Genetic Analyzer at the DNA Analysis Facility on Science Hill at Yale University (New Haven, CT).

Cloning of PCR products. Initially, 52 isolates of $P$. drechsleri and 16 isolates of $P$. cryptogea were sequenced at all loci (Table 1). All isolates within a group were found to have identical sequences based on visual inspection. For this work, a group is defined as isolates of a species collected on the same date from the same host species occurring within a growing block at a location. Visual inspection of the chromatograms revealed the presence of heterozygous sites in the ITS, $\beta$-tub, and $E F-1 \alpha$ sequences of isolates of both species. Therefore, representative

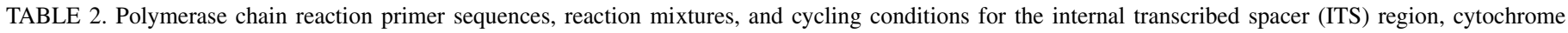
oxidase subunit II and spacer (coxII) region, $\beta$-tubulin $(\beta$-tub), and elongation factor $1 \alpha(E F-1 \alpha)$ loci

\begin{tabular}{|c|c|c|c|}
\hline Locus & Primers (reference) & Reaction mixtures in $25-\mu 1$ volumes & Cycling conditions $^{\mathrm{a}}$ \\
\hline \multirow[t]{7}{*}{ ITS } & ITS4 5' TCCTCCGCTTATTGATATGC (9) & $5 \mu \mathrm{l}$ of $5 \times$ Green GoTaq buffer ${ }^{b}$ & $94^{\circ} \mathrm{C} 3 \mathrm{~min}$ \\
\hline & ITS6 5' GAAGGTGAAGTCGTAACAAGC (9) & $1.5 \mu \mathrm{l}$ of $25 \mathrm{mM} \mathrm{MgCl}{ }_{2}$ & 30 cycles of \\
\hline & & $0.5 \mu \mathrm{l}$ of $40 \mathrm{mM}$ dNTP mix & $94^{\circ} \mathrm{C} 30 \mathrm{~s}$ \\
\hline & & $0.25 \mu \mathrm{l}$ of $50 \mu \mathrm{M}$ ITS 4 primer & $55^{\circ} \mathrm{C} 30 \mathrm{~s}$ \\
\hline & & $0.25 \mu \mathrm{l}$ of $50 \mu \mathrm{M}$ of ITS6 primer & $72^{\circ} \mathrm{C} 1 \mathrm{~min}$ \\
\hline & & $0.25 \mu \mathrm{l}$ of GoTaq Flexi DNA polymerase $\mathrm{e}^{\mathrm{b}}$ & $72^{\circ} \mathrm{C} 10 \mathrm{~min}$ \\
\hline & & $16.25 \mu \mathrm{l}$ of nuclease-free sterile water & $\ldots$ \\
\hline \multirow[t]{7}{*}{ coxII } & FM35 5' CAGAACCTTGGCAATTAGG (32) & $5 \mu \mathrm{l}$ of $5 \times$ Green GoTaq buffer & $94^{\circ} \mathrm{C} 4 \mathrm{~min}$ \\
\hline & FMPhy-10b 5' GCAAAAGCACTAAAAATTAAATATAA (34) & $3 \mu \mathrm{l}$ of $25 \mathrm{mM} \mathrm{MgCl} 2$ & 35 cycles of \\
\hline & & $0.5 \mu \mathrm{l}$ of $40 \mathrm{mM}$ dNTP mix & $94^{\circ} \mathrm{C} 30 \mathrm{~s}$ \\
\hline & & $0.5 \mu \mathrm{l}$ of $50 \mu \mathrm{M}$ FM35 primer & $59^{\circ} \mathrm{C} 30 \mathrm{~s}$ \\
\hline & & $0.5 \mu \mathrm{l}$ of $\mu \mathrm{M}$ FMPhy-10b primer & $72^{\circ} \mathrm{C} 90 \mathrm{~s}$ \\
\hline & & $0.5 \mu \mathrm{l}$ of GoTaq Flexi DNA polymerase & $72^{\circ} \mathrm{C} 10 \mathrm{~min}$ \\
\hline & & $14 \mu \mathrm{l}$ of nuclease-free sterile water & $\ldots$ \\
\hline \multirow[t]{7}{*}{$\beta$-tub } & BTubF1 5' GCCAAGTTCTGGGAGGTCATC (39) & $5 \mu \mathrm{l}$ of $5 \times$ Green GoTaq buffer & $94^{\circ} \mathrm{C} 2 \mathrm{~min}$ \\
\hline & BTubR1 5' CCTGGTACTGCTGGTACTCAG (28) & $1.5 \mu \mathrm{l}$ of $25 \mathrm{mM} \mathrm{MgCl}{ }_{2}$ & 35 cycles of \\
\hline & & $0.5 \mu \mathrm{l}$ of $40 \mathrm{mM}$ dNTP mix & $94^{\circ} \mathrm{C} 30 \mathrm{~s}$ \\
\hline & & $0.5 \mu \mathrm{l}$ of $50 \mu \mathrm{M}$ BTubF1 primer & $60^{\circ} \mathrm{C} 30 \mathrm{~s}$ \\
\hline & & $0.5 \mu \mathrm{l}$ of $\mu \mathrm{M}$ BTubR 1 primer & $72^{\circ} \mathrm{C} 1 \mathrm{~min}$ \\
\hline & & $0.25 \mu \mathrm{l}$ of GoTaq Flexi DNA polymerase & $72^{\circ} \mathrm{C} 10 \mathrm{~min}$ \\
\hline & & $15.75 \mu \mathrm{l}$ of nuclease-free sterile water & $\cdots$ \\
\hline \multirow[t]{7}{*}{$E F-1 \alpha$} & EF1AF 5' TCACGATCGACATTGCCCTG(28) & $5 \mu \mathrm{l}$ of $5 \times$ Green GoTaq buffer & $94^{\circ} \mathrm{C} 2 \mathrm{~min}$ \\
\hline & EF1AR 5' ACGGCTCGAGGATGACCATG (28) & $1.5 \mu \mathrm{l}$ of $25 \mathrm{mM} \mathrm{MgCl}_{2}$ & 35 cycles of \\
\hline & & $0.5 \mu \mathrm{l}$ of $40 \mathrm{mM}$ dNTP mix & $94^{\circ} \mathrm{C} 30 \mathrm{~s}$ \\
\hline & & $0.25 \mu \mathrm{l}$ of $50 \mu \mathrm{M}$ EF1AF primer & $60^{\circ} \mathrm{C} 30 \mathrm{~s}$ \\
\hline & & $0.25 \mu \mathrm{l}$ of $50 \mu \mathrm{M}$ of EF1AR primer & $72^{\circ} \mathrm{C} 1 \mathrm{~min}$ \\
\hline & & $0.25 \mu \mathrm{l}$ of GoTaq Flexi DNA polymerase & $72^{\circ} \mathrm{C} 10 \mathrm{~min}$ \\
\hline & & $16.25 \mu \mathrm{l}$ of nuclease-free sterile water & $\ldots$ \\
\hline
\end{tabular}

a Cycling conducted on an PTC-100 Peltier thermal cycler (MJ Research, Waltham, MA).

b Green GoTaq buffer and GoTaq Flexi DNA polymerase from Promega Corp. (Madison, WI). 
isolates for each group of isolates of $P$. cryptogea and $P$. drechsleri (Table 3) were chosen for direct cloning of PCR templates to determine alternate alleles for isolates having two or more heterozygous sites. Cloning was completed with the p-GEM T Vector System (Promega Corp.). Plasmids were purified with the UltraClean Standard Mini Plasmid Prep Kit (MO BIO Laboratories, Carlsbad, CA), and 4 to 10 clones per individual were sequenced with the universal M13 primers. Sequences for each locus were aligned, trimmed, and edited manually with Sequencher 4.9 (Genecodes, Ann Arbor, MI). Edited sequences included in analyses were deposited in GenBank (ITS, accession numbers HQ455558 to HQ455646; coxII, accession numbers HQ455741 to HQ455765; $\beta$-tub, accession numbers HQ455647 to HQ455690; and $E F-1 \alpha$ : accession numbers HQ455691 to HQ455740).

Tests of compatibility, neutrality, and population subdivision. Sequence alignments for each locus were analyzed with components of SNAP Workbench (41). Initially, the sequence alignments were collapsed with phenotype (species) into unique haplotypes with SNAP Map (1) with insertions and deletions (indels) and infinite sites violations excluded. The resulting sequence alignment for each locus was examined for site incompatibilities with SNAP Clade and Matrix (5). When incompatibilities were identified, SNAP CladeEx (5) was used to find the largest nonrecombining partitions. For loci with multiple nonrecombining partitions, each partition was subjected to all of the later analyses separately, and the results compared to determine whether the inferences changed based on the partition. Departures from neutrality were tested by examining the sequences for an excess of rare alleles using Tajima's D (43), Fu and Li's D* and F* (16), and Fu's Fs (15). Each locus was evaluated initially for population subdivision at the species level with the nonparametric tests Hudson's $\mathrm{K}_{\mathrm{ST}}(25)$ and Hudson's nearest neighbor statistic $\left(\mathrm{S}_{\mathrm{nn}}\right)$ (24). To generate the migration matrix for later coalescent analysis, the asymmetrical migration rates between $P$. cryptogea and $P$. drechsleri were estimated with the isolation with migration (IM) model (21), which allows for divergence with or without gene flow and shared common ancestry. For the IM program, two independent 6-h runs with a burn-in time of 10 million were carried out. Because IM is less robust for analyses of data from single loci, each locus was tested for equilibrium migration versus shared ancestral polymorphisms between $P$. cryptogea and $P$. drechsleri with the migration with division (MDIV) model (36). Specifically, the time of divergence (T) and the equilibrium migration parameter $(\mathrm{M})$ were estimated with MDIV and compared with the estimates from IM for agreement. The length of the Markov chain was set to 20 million and the burn-in time was 5 million for the MDIV analyses.

Coalescent analysis of $\boldsymbol{P}$. cryptogea and $\boldsymbol{P}$. drechsleri. A coalescent with subdivision model, which assumes no recombination, was implemented in Genetree version $9.0(2,19)$ to infer all possible mutational pathways and approximate the ancestry of isolates of $P$. cryptogea and $P$. drechsleri for each locus. The estimations of $\theta$ and asymmetrical migration $\left(\mathrm{M}_{\mathrm{PdPc}}\right.$ and $\left.\mathrm{M}_{\mathrm{PcPd}}\right)$ parameters obtained from the MDIV and IM analyses, respectively, were used in the likelihood estimations. For each locus, five independent runs with 10 million simulations of the coalescent for each run were performed to estimate the genealogy with the highest root probability. The resulting gene genealogies were examined for convergence. Coalescent-based trees were viewed with Treepic $(2,19)$. To estimate the time to most recent common ancestor in coalescent time units, a maximum likelihood estimate of $\theta$ was calculated based on the genealogy with the highest root probability and then coalescent simulations were performed with the estimated $\theta$ to determine the ages of mutations on the genealogy.

Minimal ancestral recombination graph. Because recombination was identified in ITS, $\beta$-tub, and $E F-l \alpha$, the ancestral history of haplotypes of each locus was reconstructed with a parsimony method that assumes mutation and recombination backward in time. Specifically, minimal ancestral recombination graphs (ARGs) were constructed. All graphs were rooted with $P$. ramorum isolate P10301. Sequences for P10301 were obtained from the Phytophthora Database (39) (accession numbers PD_00058_ITS, PD_00058_Btub, and PD_00058_EF-1 $\alpha$ ). For the ITS and $\beta$-tub loci, the branch and bound search was implemented in Beagle to identify the minimum recombination events within the histories of the isolates (30). For $E F-1 \alpha$, a heuristic

TABLE 3. Characteristics of isolates of Phytophthora cryptogea and P. drechsleri cloned, sequenced, and analyzed

\begin{tabular}{|c|c|c|c|c|c|c|c|c|}
\hline \multirow[b]{2}{*}{ Isolate } & \multirow[b]{2}{*}{ Group $^{\mathrm{a}}$} & \multirow[b]{2}{*}{ Species } & \multirow[b]{2}{*}{ Year } & \multirow[b]{2}{*}{ Host } & \multirow[b]{2}{*}{ Location } & \multirow[b]{2}{*}{ Mating type } & \multicolumn{2}{|c|}{ Growth rate $(\mathrm{mm} /$ day $)$ at } \\
\hline & & & & & & & $20^{\circ} \mathrm{C}$ & $35^{\circ} \mathrm{C}$ \\
\hline P1088/ATCC46721b & $\ldots$ & P. cryptogea & 1935 & China aster & California & A1 & 9.8 & 0 \\
\hline NC108 & Pc1 & P. cryptogea & 2007 & Gerbera daisy & B & A1 & 15.4 & 3.1 \\
\hline NC110 & Pc1 & P. cryptogea & 2007 & Gerbera daisy & $\mathrm{B}$ & A1 & 14.8 & 2.8 \\
\hline NC208 & $\mathrm{Pc} 2$ & P. cryptogea & 2008 & Blue daze & $\mathrm{C}$ & $\mathrm{A} 2$ & 13.9 & 0 \\
\hline NC594 & Pc3 & P. cryptogea & 2008 & Gerbera daisy & $\mathrm{E}$ & $\mathrm{A} 2$ & 16.4 & 2.7 \\
\hline NC597 & Pc3 & P. cryptogea & 2008 & Gerbera daisy & $\mathrm{E}$ & $\mathrm{A} 2$ & 16.1 & 4.1 \\
\hline NC1105 & $\operatorname{Pc} 4$ & P. cryptogea & 2008 & Verbena & I & A1 & 16.1 & 3.0 \\
\hline NC1146 & Pc5 & P. cryptogea & 2008 & Dusty miller & $\mathrm{J}$ & $\mathrm{A} 2$ & 12.1 & 0 \\
\hline NC1151 & $\operatorname{Pc} 5$ & P. cryptogea & 2008 & Dusty miller & $\mathrm{J}$ & A2 & 12.0 & 0 \\
\hline P1087/ATCC46724 ${ }^{\mathrm{b}}$ & $\ldots$ & P. drechsleri & 1936 & Beet & California & $\mathrm{A} 2$ & 6.3 & 6.8 \\
\hline NC88 & $\mathrm{Pd} 1$ & P. drechsleri & 2007 & Gerbera daisy & $\mathrm{B}$ & A1 & 14.6 & 14.2 \\
\hline $\mathrm{NC} 103$ & Pd1 & P. drechsleri & 2007 & Gerbera daisy & B & A1 & 12.5 & 10.9 \\
\hline NC947 & $\mathrm{Pd} 2$ & P. drechsleri & 2008 & Gerbera daisy & $\mathrm{G}$ & A1 & 16.7 & 11.7 \\
\hline NC955 & $\mathrm{Pd} 2$ & P. drechsleri & 2008 & Gerbera daisy & $\mathrm{G}$ & A1 & 15.8 & 11.8 \\
\hline NC957 & $\mathrm{Pd} 3$ & P. drechsleri & 2008 & Fuchsia & $\mathrm{G}$ & A1 & 13.5 & 11.8 \\
\hline NC961 & $\mathrm{Pd} 3$ & P. drechsleri & 2008 & Fuchsia & $\mathrm{G}$ & A1 & 14.1 & 11.4 \\
\hline NC966 & $\mathrm{Pd} 4$ & P. drechsleri & 2008 & Gerbera daisy & $\mathrm{G}$ & A1 & 12.2 & 11.6 \\
\hline CRGB6 & $\mathrm{Pd} 5$ & P. drechsleri & 2002 & Gerbera daisy & B & A1 & 15.6 & 12.5 \\
\hline CRGB42 & $\mathrm{Pd} 5$ & P. drechsleri & 2002 & Gerbera daisy & B & A1 & 10.0 & 9.2 \\
\hline FDM5 & Pd6 & P. drechsleri & 2001 & Dusty miller & A & A1 & 17.0 & 14.5 \\
\hline FDM14 & Pd6 & P. drechsleri & 2001 & Dusty miller & A & A1 & 14.6 & 14.2 \\
\hline FWDM20 & $\operatorname{Pd} 7$ & P. drechsleri & 2002 & Dusty miller & A & A1 & 13.6 & 13.3 \\
\hline FWDM25 & $\operatorname{Pd} 7$ & P. drechsleri & 2002 & Dusty miller & A & A1 & 14.3 & 14.3 \\
\hline FWGB4 & $\mathrm{Pd} 8$ & P. drechsleri & 2002 & Gerbera daisy & A & A1 & 13.3 & 13.2 \\
\hline FWGB7 & $\operatorname{Pd} 8$ & P. drechsleri & 2002 & Gerbera daisy & A & A1 & 10.2 & 8.5 \\
\hline
\end{tabular}

${ }^{a}$ For this work, a group is defined as isolates collected on the same date from the same host species occurring within a growing block at a location.

b Isolate obtained from World Oomycete Genetic Resource Collection; ATCC = American Type Culture Collection (44,46). 
implementation of Beagle was conducted with the program Kwarg because the exhaustive branch and bound search could not go to completion (30). Five independent Kwarg simulations were run to ensure that similar ancestral histories were found.

\section{RESULTS}

Population genetic analyses. Successful amplification of all loci investigated was obtained for all isolates of P. cryptogea and $P$. drechsleri. The total number of sequences of $P$. cryptogea and $P$. drechsleri analyzed varied by locus because of the presence of heterozygosity in some isolates at some loci and not at others (Table 4). A high level of variability, represented by a large number of rare single-nucleotide polymorphisms (SNPs) found in single clone sequences, was found in the ITS repeat array within an individual isolate. Because of this, only phylogenetically informative sites were retained in the sequence alignment and subjected to further analyses. In addition, an analysis of a concatenated data set containing all loci was not possible because of the heterozygosity and the difficulty of resolving the phase of alleles at multiple loci. Initially, 30, 8, 16, and 40 haplotypes were identified for the ITS, coxII, $\beta$-tub, and $E F-1 \alpha$ loci, respectively (Supplemental Figure 1). There were 33 variable sites in the ITS and coxII regions, 36 variable sites in $\beta$-tub, and 38 variable sites in $E F-1 \alpha$.

Incompatibilities among pairs of variable sites were identified in the compatibility matrices of all loci. The incompatibilities identified in the coxII locus appear to be mutational hotspots rather than recombination events because mitochondrial DNA generally does not undergo recombination, and clear recombi- nation breakpoints were not evident in the compatibility matrix (data not shown). All incompatibilities were excluded because these variable positions violate the assumption of an infinite sites model, which is required for subsequent coalescent analysis. SNAP CladeEx identified two nonrecombining partitions for the ITS, $\beta$-tub, and $E F-1 \alpha$ loci and a single nonrecombining partition for the coxII region. This reduced the number of segregating sites $(s)$ included in subsequent analyses (Table 4). Isolates of $P$. cryptogea had higher average numbers of pairwise nucleotide differences $(k)$ than isolates of $P$. drechsleri for all loci (Table 4). The highest $k$ for $P$. cryptogea and $P$. drechsleri was obtained for $\beta$-tub ( $k=7.44$ and 2.24 , respectively), and the lowest average number of nucleotide differences for both species was estimated for the ITS region (P. cryptogea: $k=2.80$ and P. drechsleri: $k=$ $0.44)$.

All neutrality tests for all loci of isolates of $P$. cryptogea and $P$. drechsleri were not significant (data not shown) based on examining the sequences for an excess of rare nucleotides. This suggests that the loci have not been under selection and that the populations are at equilibrium. Population subdivision between $P$. cryptogea and $P$. drechsleri was detected with Hudson's $\mathrm{K}_{\mathrm{ST}}$ and Hudson's $S_{n n}$ tests. The tests of population subdivision between the species were significant for all loci (Table 5). The estimates of time to divergence $(\mathrm{T})$ and the equilibrium migration parameter (M) obtained with MDIV (Table 5) were consistent with the tests of population subdivision and indicate divergence of $P$. cryptogea and $P$. drechsleri, with negligible migration between the species. The $\mathrm{T}$ of the species varied by locus. For the ITS and coxII loci, the $\mathrm{T}$ estimates suggest a moderate divergence time $(\mathrm{T}=7.2$ and 4.5 , respectively); whereas the $\beta$-tub and $E F-1 \alpha$ indicate a rela-

TABLE 4. Summary population statistics of DNA polymorphisms in isolates of Phytophthora cryptogea and P. drechsleri from floriculture crops produced in North Carolina greenhouse facilities based on sequences of the internal transcribed spacer (ITS) and cytochrome oxidase subunit II and spacer (coxII) regions and the $\beta$-tubulin $(\beta$-tub) and elongation factor $1 \alpha(E F-1 \alpha)$ genes

\begin{tabular}{|c|c|c|c|c|c|c|}
\hline Locus & Species & Length $(\mathrm{bp})^{\mathrm{a}}$ & Sample size $^{b}$ & Segregating nucleotide sites & Nucleotide differences $^{\mathrm{c}}$ & $\theta^{\mathrm{d}}$ \\
\hline ITS & P. cryptogea & 785 & 50 & 12 & 2.80 & 2.68 \\
\hline coxII & P. cryptogea & 930 & 9 & 16 & 4.94 & 5.89 \\
\hline \multirow[t]{2}{*}{$\beta-t u b$} & P. cryptogea & 1,113 & 12 & 19 & 7.44 & 6.29 \\
\hline & P. drechsleri & 1,113 & 32 & 8 & 2.24 & 1.99 \\
\hline \multirow[t]{2}{*}{$E F-1 \alpha$} & P. cryptogea & 891 & 18 & 16 & 4.60 & 4.65 \\
\hline & P. drechsleri & 891 & 32 & 7 & 1.42 & 1.74 \\
\hline
\end{tabular}

${ }^{a}$ Consensus sequence length for alignment containing DNA sequences for $P$. cryptogea and $P$. drechsleri.

${ }^{\mathrm{b}}$ Number of DNA sequences included in the phylogenetic analyses.

${ }^{c}$ Average number of pairwise nucleotide differences.

${ }^{\mathrm{d}}$ Coalescent-based estimate of $\theta$ per locus.

TABLE 5. Test statistics for population subdivision and population parameters based on variation in the internal transcribed spacer (ITS) and cytochrome oxidase II and internal spacer (coxII) regions and $\beta$-tubulin $(\beta$-tub) and elongation factor $1 \alpha(E F-1 \alpha)$ genes of isolates of Phytophthora cryptogea and P. drechsleri collected from floriculture crops produced in North Carolina commercial greenhouses

\begin{tabular}{|c|c|c|c|c|c|c|c|c|}
\hline Locus $^{\mathrm{a}}$ & 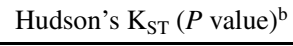 & Hudson's $\mathrm{S}_{\mathrm{nn}}(P \text { value })^{\mathrm{c}}$ & $\theta^{\mathrm{d}}$ & $\mathrm{T}^{\mathrm{e}}$ & $\mathrm{M}^{\mathrm{f}}$ & $\mathrm{M}_{\mathrm{PdPc}^{\mathrm{g}}}$ & $\mathrm{M}_{\mathrm{PcPd}^{\mathrm{g}}}^{\mathrm{g}}$ & TMRCA $^{\mathrm{h}}$ \\
\hline ITS & $0.54(P=0.0000)^{*}$ & $0.99(P=0.0000)^{*}$ & 1.46 & 7.2 & $<0.01$ & 0.245 & 0.065 & 7.68 \\
\hline coxII & $0.17(P=0.0230)^{*}$ & $0.82(P=0.0002)^{*}$ & 3.39 & 4.5 & $<0.01$ & 0.275 & 0.105 & 5.08 \\
\hline$\beta$-tub & $0.08(P=0.0020) *$ & $0.90(P=0.0000) *$ & 4.14 & 2.0 & 0.01 & 0.125 & 0.145 & 4.36 \\
\hline
\end{tabular}

a Parameter estimates for each locus are for the nonrecombining partitions shown in the Figure 1 gene genealogies.

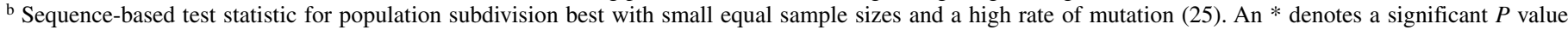
$(P \leq 0.05)$, indicating population subdivision between isolates of $P$. cryptogea and $P$. drechsleri.

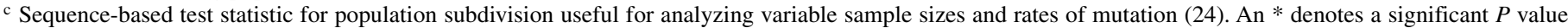
$(P \leq 0.05)$, indicating population subdivision between isolates of $P$. cryptogea and $P$. drechsleri.

${ }^{\mathrm{d}}$ Coalescent-based estimate of $\theta$ per locus calculated with Genetree $(2,19)$.

e Time to divergence (T) between species estimated from the posterior probability distribution calculated with migration with division (MDIV) (36).

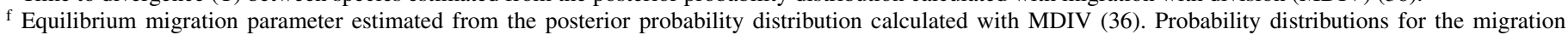
parameter estimates are given in Supplementary Figure 2.

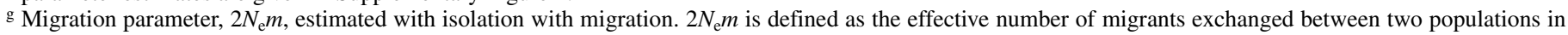
each generation, where $N_{\mathrm{e}}$ is the effective population size and $m$ is the migration rate per generation. $\mathrm{M}_{\mathrm{PdPc}}$ is migration from $P$. drechsleri to $P$. cryptogea and $\mathrm{M}_{\mathrm{PcPd}}$ is migration from $P$. cryptogea to P. drechsleri. (36). Probability distributions for the migration parameter estimates are given in Supplementary Figure 3.

h Coalescent-based estimate of the time to most recent common ancestor (TMRCA) of the sample sequences. 

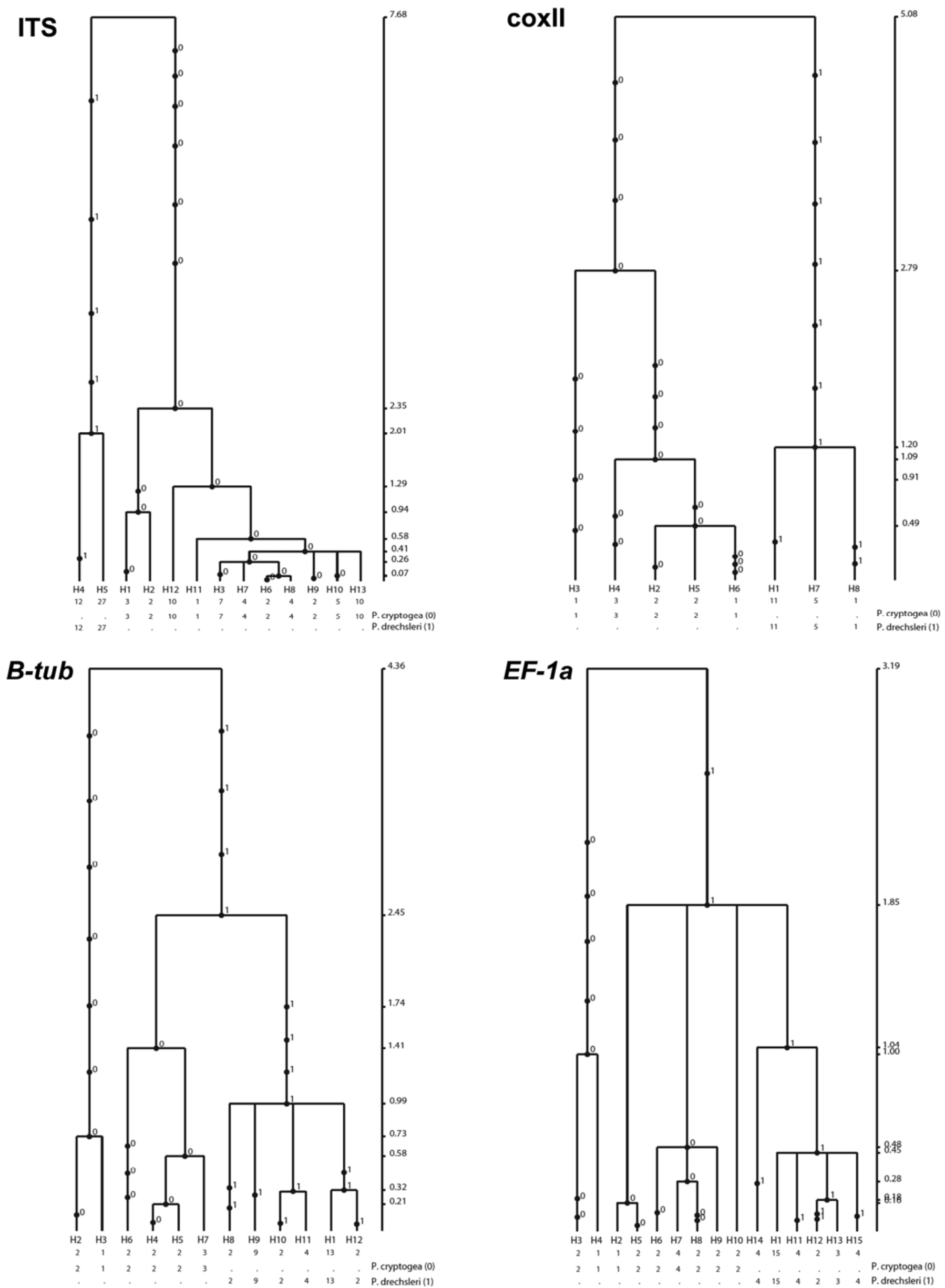
tively short divergence time ( $\mathrm{T}=2.0$ and 1.3 , respectively) (Table 5). The asymmetrical migration parameters $\left(\mathrm{M}_{\mathrm{PdPc}}\right.$ and $\left.\mathrm{M}_{\mathrm{PcPd}}\right)$ estimated with IM were consistent with the equilibrium migration estimates (Table 5) and indicate no evidence of gene flow between floriculture isolates of $P$. cryptogea and $P$. drechsleri obtained from North Carolina greenhouse facilities.

Coalescent analysis. The coalescent simulations inferred a single gene genealogy with the highest root probability for the coxII locus and two genealogies with the highest root probability for each nonrecombining partition of the ITS, $\beta$-tub, and $E F-1 \alpha$ loci. First, for ITS, $\beta$-tub, and $E F-1 \alpha$, the two genealogies for each partition of a locus were compared. For all three loci, the genealogies had similar topologies with only minor differences in the positions of mutations in the deepest branches of the tree. Next, the genealogies for the two partitions for each locus were compared. One tree is shown for each locus (Fig. 1) because only minor differences in isolate distributions were found between genealogies inferred from each nonrecombining partition. For the ITS partitions, $\mathrm{NC1105}(e, h)$ of haplotype $\mathrm{H} 10$ were switched with $\mathrm{NC} 1105(b, i)$ of H13. For the $\beta$-tub partitions, P1088 $(b)$ of $\mathrm{H} 2$ exchanged with $\mathrm{NC} 208$ of $\mathrm{H} 3$, and haplotypes $\mathrm{H} 9$ and $\mathrm{H} 10$ were collapsed into a single haplotype in the other $E F-1 \alpha$ partition. The distribution of isolates and clone variants for each locus for the shown genealogies is given in Table 6 .

For the ITS locus, 12 haplotypes were inferred based on 25 mutations (Fig. 1). Twelve mutations were fixed between the haplotypes comprised of $P$. cryptogea isolates $(\mathrm{H} 1, \mathrm{H} 2, \mathrm{H} 3, \mathrm{H} 6$, $\mathrm{H} 7, \mathrm{H} 8, \mathrm{H} 9, \mathrm{H} 10, \mathrm{H} 11$, and H12) and the haplotypes associated with isolates of $P$. drechsleri (H4 and H5). The genealogy inferred from the coxII locus was similar to the ITS region (Fig. 1). In total, 30 mutations were associated with eight haplotypes, with 11 mutations fixed between haplotypes consisting of isolates of $P$. cryptogea $(\mathrm{H} 2, \mathrm{H} 3, \mathrm{H} 4, \mathrm{H} 5$, and $\mathrm{H} 6)$ and haplotypes containing $P$. drechsleri isolates $(\mathrm{H} 1, \mathrm{H} 7$, and $\mathrm{H} 8)$.

In the genealogy inferred for the $\beta$-tub locus, 12 haplotypes were inferred from 31 mutations (Fig. 1). Haplotypes H2, H3, H4, $\mathrm{H} 5, \mathrm{H} 6$, and $\mathrm{H} 7$ were composed of $P$. cryptogea isolates, and haplotypes $\mathrm{H} 1, \mathrm{H} 8, \mathrm{H} 9, \mathrm{H} 10, \mathrm{H} 11$, and $\mathrm{H} 12$ were associated with isolates of $P$. drechsleri. Eleven fixed mutations separated haplotypes $\mathrm{H} 2$ and $\mathrm{H} 3$, consisting of $P$. cryptogea isolates, from all other haplotypes, and five mutations were fixed between the remaining haplotypes associated with $P$. cryptogea $(\mathrm{H} 4, \mathrm{H} 5, \mathrm{H} 6$, and H7) and all haplotypes composed of isolates of P. drechsleri. Similarly, in the genealogy inferred from $E F-1 \alpha$ (Fig. 1), 24 mutations were associated with 15 haplotypes with 7 fixed mutations separating haplotypes $\mathrm{H} 3$ and $\mathrm{H} 4$ consisting of $P$. cryptogea isolates and a single fixed mutation separating the remaining haplotypes associated with isolates of $P$. cryptogea $(\mathrm{H} 2, \mathrm{H} 5, \mathrm{H} 6, \mathrm{H} 7, \mathrm{H} 8$, and H9) and all haplotypes composed of $P$. drechsleri isolates (H1, H11, H12, H13, H14, and H15).

Minimal ARG of $\boldsymbol{P}$. cryptogea and $\boldsymbol{P}$. drechsleri haplotypes. In total, 14 recombination events were inferred in the history of the ITS locus (Fig. 2). All haplotypes composed of P. drechsleri isolates (H12, H13, H14, and H15) have experienced recombination in their history. In contrast, haplotypes H5, H18, H20, $\mathrm{H} 24$, and $\mathrm{H} 25$ associated with $P$. cryptogea isolates coalesced to a common ancestor without recombination. Recombination events were inferred within the histories of the remaining haplotypes composed of $P$. cryptogea isolates $(\mathrm{H} 1, \mathrm{H} 2, \mathrm{H} 3, \mathrm{H} 4, \mathrm{H} 6, \mathrm{H} 7, \mathrm{H} 8$, $\mathrm{H} 9, \mathrm{H} 10, \mathrm{H} 11, \mathrm{H} 16, \mathrm{H} 17, \mathrm{H} 19, \mathrm{H} 21, \mathrm{H} 22, \mathrm{H} 23$, and H26). At least two inferred recombination events consisted of isolates of $P$. cryptogea of different mating types (A1 and A2, respectively) (Fig. 2). One putative recombination event occurred between a haplotype comprising $P$. drechsleri A1 isolates (H12) and a haplotype associated with $P$. cryptogea A1 and A2 isolates $(\mathrm{H} 2)$.

Seven recombination events were inferred in the history of the ARG for the $\beta$-tub gene (Fig. 3). All haplotypes composed of $P$. drechsleri isolates $(\mathrm{H} 2, \mathrm{H} 9, \mathrm{H} 10, \mathrm{H} 11, \mathrm{H} 12, \mathrm{H} 13$, and $\mathrm{H} 14)$ and haplotypes $\mathrm{H} 3, \mathrm{H} 4, \mathrm{H} 5, \mathrm{H} 6, \mathrm{H} 7$, and $\mathrm{H} 8$ associated with $P$. cryptogea isolates have experienced recombination. Only haplotype $\mathrm{H} 7$, consisting of $P$. cryptogea isolates, coalesced without recombination. Two putative recombination events occurred between haplotypes associated with each species. A recombination event between $\mathrm{H} 2$ ( $P$. drechsleri A1 isolates) and H8 (P. cryptogea $\mathrm{A} 1$ and $\mathrm{A} 2$ isolates) resulted in $\mathrm{H} 13$ and $\mathrm{H} 14$ ( $P$. drechsleri A1 isolates) (Fig. 3). Likewise, a recombination event between $\mathrm{H} 10$ (P. drechsleri A1 isolates) and $\mathrm{H} 8$ (P. cryptogea A1 and A2 isolates) gave rise to $\mathrm{H} 11$ ( $P$. drechsleri A1 isolates) (Fig. 3).

In all sampled ancestral histories of $E F-1 \alpha$, isolates of $P$. cryptogea and $P$. drechsleri had undergone recombination (data not shown). In total, 34 to 37 recombination events were inferred in the sampled ARGs; however, no clear recent recombination events occurred between $P$. cryptogea and $P$. drechsleri. A single recombination event between A1 and A2 P. cryptogea isolates was inferred.

\section{DISCUSSION}

The genetic relatedness and ancestry of isolates of $P$. cryptogea and $P$. drechsleri collected from floriculture crops in North Carolina commercial greenhouse facilities was investigated. To accomplish this, two distinct types of analyses were used: (i) maximum likelihood with a coalescent analysis assuming no recombination and population subdivision and (ii) parsimony analysis assuming recombination with an ARG. Overall, the gene genealogies inferred from the coalescent-based analysis support a common ancestry with a recent divergence for the investigated isolates of $P$. cryptogea and $P$. drechsleri. In a study of a collection of 28 isolates of $P$. cryptogea and 14 isolates of $P$. drechsleri of worldwide origin, Mostowfizadeh-Ghalamfarsa et al. (35) found $P$. cryptogea and $P$. drechsleri to be distinct species based on gene phylogenies inferred with a neighbor-joining method. The gene phylogenies for the five individual loci and the combined loci evaluated by Mostowfizadeh-Ghalamfarsa et al. (35) were congruent. In contrast, in our study, different evolutionary histories are evident depending on the locus analyzed. All loci infer common ancestry for isolates of $P$. cryptogea and P. drechsleri; however, the level of divergence varies by locus. The coalescent analysis of the ITS and coxII regions inferred that $P$. cryptogea and $P$. drechsleri are closely related sister species which clearly have diverged at a constant rate from a common ancestor. Each species forms a monophyletic group within the gene genealogies, with $P$. cryptogea more genetically diverse than $P$. drechsleri. However, the genealogies inferred from the $B-t u b$ and $E F-1 \alpha$ genes were in conflict with the ITS and coxII regions. In the $\beta$-tub and $E F-1 \alpha$ genes, there was not a clear divergence of the two

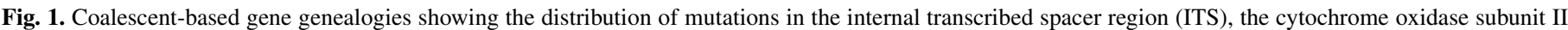

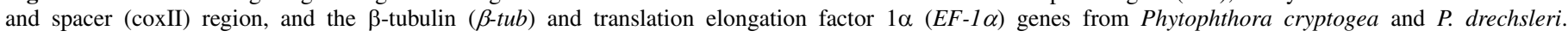

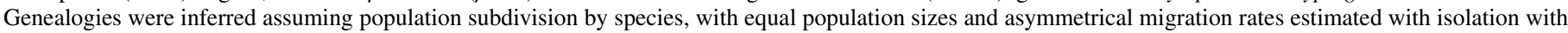

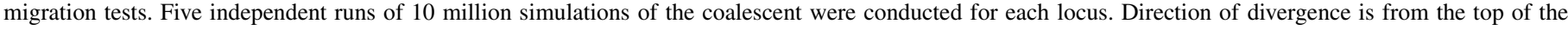

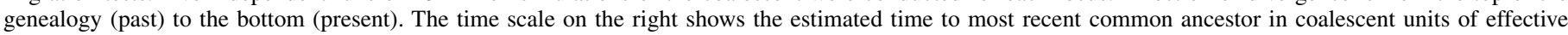

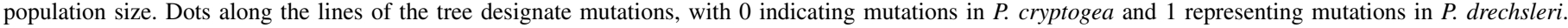

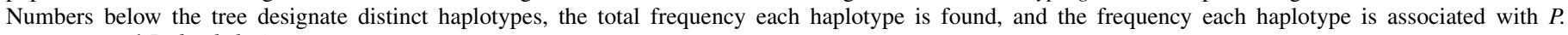
cryptogea and $P$. drechsleri. 
species for our group of isolates, and the $\beta$-tub and $E F-1 \alpha$ genealogies suggest that $P$. cryptogea and $P$. drechsleri are incipient species that are in the process of diverging. The differences in phylogenetic inferences between loci are likely a result of the differences in the evolutionary histories of the loci. In diploid organisms, such as Phytophthora spp., haploid mitochondrial DNA evolves faster than single-copy nuclear genes, such as $\beta$-tub and $E F-1 \alpha$, because mitochondrial DNA has a greater rate of nucleotide substitution from a lack of DNA polymerase proofreading function (20). Therefore, nuclear genes reveal more ancient population processes and mitochondrial regions provide better resolution of more recent population processes. The nuclear $\beta$-tub and $E F-1 \alpha$ loci suggest that speciation is still underway for our isolates of $P$. cryptogea and $P$. drechsleri, whereas the mitochondrial coxII region inferred clear divergence of the two species with fixed polymorphisms for each species. In addition, the rDNA ITS repeat provided some resolution of more recent population processes, as indicated by the divergence of $P$. cryptogea and $P$. drechsleri. However, for several isolates of $P$. cryptogea and $P$. drechsleri, it appears that convergent evolution through the processes of gene conversion and unequal crossing over has not had sufficient time to homogenize the rDNA repeat array, as is evident by the level of variability observed between cloned copies of the ITS repeat of an individual (20). The incongruence between gene genealogies highlights the need for loci with differing evolutionary histories to provide multiple levels of resolution when researching the phylogenetic history of a population, particularly with a population that may not have welldefined species boundaries, as is often the case with species of Phytophthora (27). In addition, researchers will have to take care when choosing loci for DNA-based methods to differentiate these species because regions of a gene could be more like one species or the other.

Phylogenetic relationships between species that vary by the genomic region studied can be a good indication of past recombination events (38). Recombination between two close species is

TABLE 6. Distribution of haplotypes and isolates based on coalescent analysis of the internal transcribed spacer (ITS) and cytochrome oxidase II and internal spacer (coxII) regions and the $\beta$-tubulin $(\beta$-tub) and elongation factor $1 \alpha(E F-1 \alpha)$ genes of Phytophthora cryptogea and P. drechsleri

\begin{tabular}{|c|c|c|}
\hline Locus & $\begin{array}{l}\text { Haplotype } \\
\text { (frequency) }\end{array}$ & Isolates (clone sequence variant) \\
\hline \multirow{10}{*}{ ITS } & $1(3)$ & P. cryptogea $\mathrm{P} 1088, \mathrm{NC} 208(b, c)$ \\
\hline & $2(2)$ & P. cryptogea $\mathrm{NC} 208(f, g)$ \\
\hline & $4(12)$ & P. drechsleri $\mathrm{NC} 88(d, f, h), \mathrm{NC103}(a, d), \mathrm{CRGB} 6(e-g), \mathrm{CRGB} 42(a, e, h, j)$ \\
\hline & $5(27)$ & $\begin{array}{l}\text { P. drechsleri P1087, NC88 (a,c,e), NC103 }(b, c, e, f) \text {, NC947, NC955, NC957, NC961, NC966, CRGB }(a-d, h, l) \text {, CRGB42 (d), FDM5, } \\
\text { FDM14, FWDM20, FWDM25, FWGB4, FWGB7 }\end{array}$ \\
\hline & $6(2)$ & P. cryptogea $\mathrm{NC} 110(d, l)$ \\
\hline & $9(2)$ & P. cryptogea $\mathrm{NC5} 94(d), \mathrm{NC5} 57(d)$ \\
\hline & $10(5)$ & P. cryptogea $\mathrm{NC} 1105(a, c, e, f, h)$ \\
\hline & $11(1)$ & P. cryptogea $\mathrm{NC108}(f)$ \\
\hline & $12(10)$ & P. cryptogea $\mathrm{NC} 208(a, e, h), \mathrm{NC} 1146(a-d), \mathrm{NC} 1151(a-c)$ \\
\hline & $13(10)$ & P. cryptogea $\mathrm{NC} 108(g), \mathrm{NC} 110(f, h), \mathrm{NC} 594(e), \mathrm{NC} 597(c, e), \mathrm{NC} 1105(b, d, g, i)$ \\
\hline \multirow{3}{*}{ coxII } & $1(10)$ & P. drechsleri NC947, NC955, NC957, NC961, FDM5, FDM14, FWDM20, FWDM25, FWGB4, FWGB7 \\
\hline & $2(2)$ & P. cryptogea $\mathrm{NC} 108, \mathrm{NC} 110$ \\
\hline & $8(1)$ & P. drechsleri P1087 \\
\hline \multirow[t]{11}{*}{$\beta-t u b$} & $1(13)$ & $\begin{array}{l}\text { P. drechsleri NC88 }(b) \text {, NC103 }(b) \text {, NC947 }(b) \text {, NC955 }(b) \text {, NC961 }(b) \text {, NC966 (b), CRGB6 }(b) \text {, CRGB42 }(b) \text {, FDM5 }(b) \text {, FDM14 }(b) \text {, } \\
\text { FWG4 }(b) \text {, FWGB7 }(b)\end{array}$ \\
\hline & $2(2)$ & P. cryptogea $\mathrm{P} 1088$ (a), NC208 \\
\hline & $3(1)$ & P. cryptogea $\mathrm{P} 1088(b)$ \\
\hline & $4(2)$ & P. cryptogea $\mathrm{NC} 108(b), \mathrm{NC} 110(b)$ \\
\hline & $5(2)$ & P. cryptogea $\mathrm{NC} 108$ (a), NC110 (a) \\
\hline & $6(2)$ & P. cryptogea $\mathrm{NC} 1146, \mathrm{NC} 1151$ \\
\hline & $7(3)$ & P. cryptogea $\mathrm{NC} 594, \mathrm{NC} 597, \mathrm{NC} 1105$ \\
\hline & $8(2)$ & P. drechsleri $\mathrm{P} 1087(a, b)$ \\
\hline & $9(9)$ & P. drechsleri NC947 (a), NC955 (a), NC957 (a), NC961 (a), NC966 (a), FDM5 (a), FDM14 (a), FWGB4 (a), FWGB7 (a) \\
\hline & $10(2)$ & P. drechsleri FWDM20 (a), FWDM25 (a) \\
\hline & $11(4)$ & P. drechsleri $\mathrm{NC} 88(a), \mathrm{NC} 103(a), \mathrm{CRGB} 6(a), \mathrm{CRGB} 42(a)$ \\
\hline & $9(2)$ & P. cryptogea $\mathrm{NC108}(b), \mathrm{NC110}(b)$ \\
\hline & $10(2)$ & P. cryptogea NC594 (a), NC597 (a) \\
\hline & $11(4)$ & P. drechsleri NC947 (a), NC955 (a), NC966 $(a, b)$ \\
\hline & $12(2)$ & P. drechsleri $\mathrm{NC} 88(a), \mathrm{NC103}(a)$ \\
\hline & $13(3)$ & P. drechsleri P1087 (b), FWDM20 (b), FWDM25 (b) \\
\hline & $14(4)$ & P. drechsleri FDM5 (b), FWDM25 (a), FWGB4 (b), FWGB7 (a) \\
\hline & $15(4)$ & P. drechsleri NC88 (b), NC103 (b), CRGB6 (a), CRGB42 (a) \\
\hline
\end{tabular}


known to complicate phylogenetic analyses by reducing fixed DNA sequence differences between the species (38). The coalescent-based analyses inferred the breakup of monophyly of $P$. cryptogea in the $\beta$-tub and EF-1 $\alpha$ loci and grouping of some isolates of $P$. cryptogea more closely with haplotypes of $P$. drechsleri than haplotypes of $P$. cryptogea. However, because the coalescent-based model used for the analysis assumes no recombination, the resulting gene genealogies failed to infer the full extent of the relationship between $P$. cryptogea and $P$. drechsleri that is revealed in the ITS and $\beta$-tub ARGs because it takes recombination into account when reconstructing the evolutionary history of populations. The inferred ARGs of the ITS region and $\beta$-tub gene suggest that genetic exchange has occurred within the phylogenetic history of the isolates of $P$. cryptogea and $P$. drechsleri collected from North Carolina greenhouses. Specifically, one recombination event between haplotypes associated with isolates of $P$. cryptogea and $P$. drechsleri was inferred in the ITS ARG, and two inferred recombination events occurred between the species in the $\beta$-tub ARG. Recombination between the two species explains the lack of clear divergence in the nuclear gene genealogies. Using similar methodology to analyze $P$. ramorum lineages, Goss et al. (18) found phylogenetic conflict between loci which was explained by ancient recombination events between lineages. Genetic exchange between species of Phytophthora in agricultural and natural systems is not without precedent (11). The new species, $P$. alni, was identified as a hybrid of $P$. cambivora and a $P$. fragariae-like species $(6,7)$. Similarly, a hybrid of $P$. nicotianae and $P$. cactorum was found on ornamental plants in greenhouses in The Netherlands $(4,31)$.

In the ITS and $\beta$-tub ARGs, the inferred recombination events occurred between haplotypes of $P$. drechsleri and $P$. cryptogea consisting of isolates of A1 and A2 mating types, respectively. This suggests that sexual reproduction has occurred between $P$. cryptogea and $P$. drechsleri. Experimental crosses between $P$.

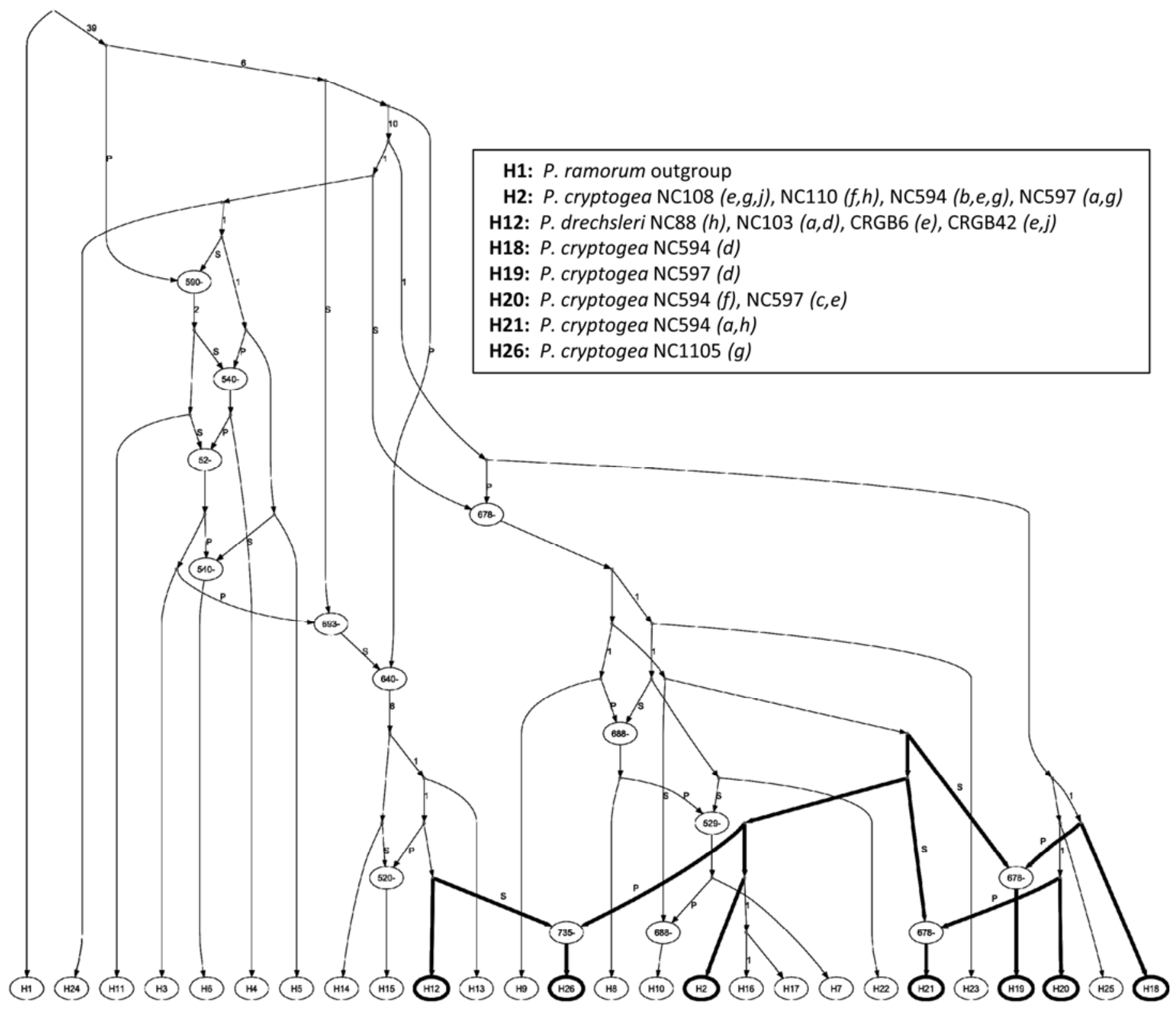

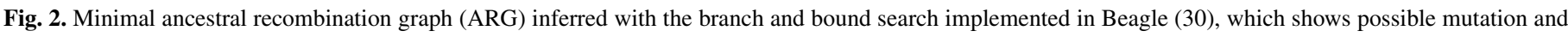

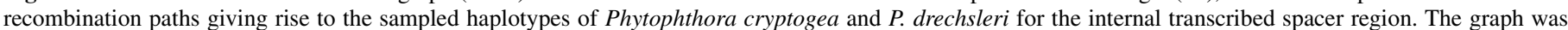

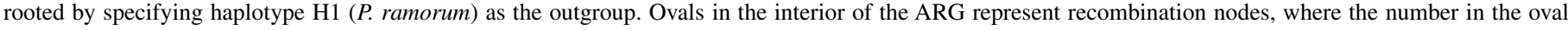

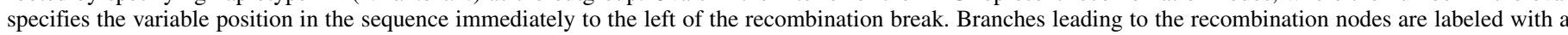

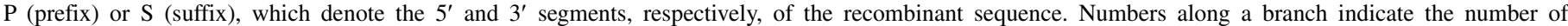

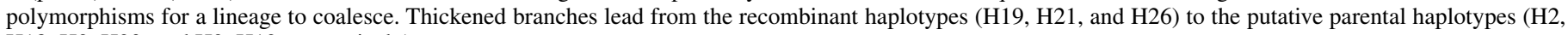
$\mathrm{H} 18$; $\mathrm{H} 2, \mathrm{H} 20$; and $\mathrm{H} 2, \mathrm{H} 12$, respectively). 
drechsleri isolates and P. cryptogea isolates produced oospores (data not shown) but it is unknown whether the progeny are hybrids or the result of induced selfing. Additional studies evaluating sexual reproduction between $P$. cryptogea and $P$. drechsleri and the characteristics of any resulting progeny are needed because understanding the potential for outcrossing could be critical for disease management. Sexual reproduction between $P$. cryptogea and $P$. drechsleri could result in the development of more fit genotypes and potentially allow the introgression of mefenoxam resistance from $P$. drechsleri to $P$. cryptogea, a species for which mefenoxam resistance has not yet been reported.

In most species of Phytophthora, including P. cryptogea, the importance and occurrence of sexual reproduction in agricultural and natural settings is unknown. The A1 and A2 mating types of P. cryptogea were collected in North Carolina during the 2007 and 2008 survey of greenhouse facilities (37). The A1 and A2

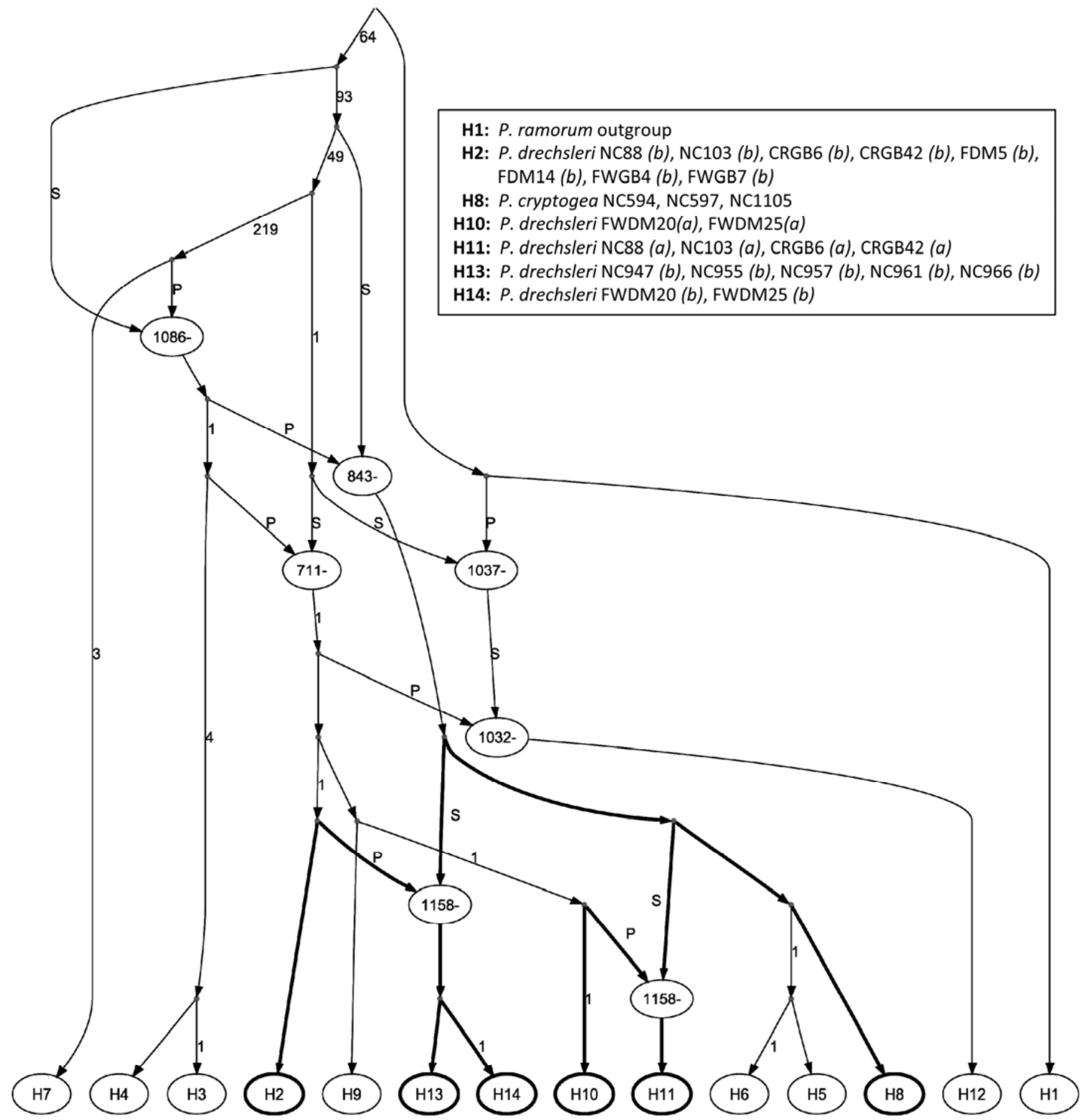

Fig. 3. Minimal ancestral recombination graph (ARG) inferred with the branch and bound search implemented in Beagle (30), which shows possible mutation and recombination paths giving rise to the sampled haplotypes of Phytophthora cryptogea and $P$. drechsleri for the $\beta$-tubulin gene. The graph was rooted by specifying haplotype H1 (P. ramorum) as the outgroup. Ovals in the interior of the ARG represent recombination nodes, where the number in the oval specifies the variable position in the sequence immediately to the left of the recombination break. Branches leading to the recombination nodes are labeled with a $\mathrm{P}$ (prefix) or $\mathrm{S}$ (suffix), which denote the $5^{\prime}$ and $3^{\prime}$ segments, respectively, of the recombinant sequence. Numbers along a branch indicate the number of polymorphisms for a lineage to coalesce. Thickened branches lead from the recombinants (H11 and H13, H14) to the putative parental haplotypes (H8, H10 and H2, H8, respectively). 
isolates of $P$. cryptogea shared haplotypes in the gene genealogies inferred from the ITS, $\beta$-tub, and $E F-1 \alpha$ loci. In addition, recombination between haplotypes composed of isolates of $P$. cryptogea of A1 and A2 mating types were inferred in the ITS and $E F-1 \alpha$ ARGs. This suggests that sexual reproduction has occurred in the evolutionary history of these isolates of P. cryptogea, and the variability observed between cloned copies of the ITS repeat of an individual is likely a result of outcrossing. MostowfizadehGhalamfarsa et al. (35) identified three P. cryptogea subgroups with evidence of genetic exchange between two lineages to form an intermediate lineage.

In the floriculture industry, it is common for plant material to move around the United States and even from off-shore into the United States (10). This movement of plant material allows the movement of new pathogens and new genetic isolates of existing pathogens into production areas. By identifying unique genotypes of a species of Phytophthora, the origin of inoculum and pathway of movement of Phytophthora spp. within a commodity can potentially be detected. The genealogy of the coxII locus identified a possible greenhouse location where $P$. drechsleri may have become established onsite. Isolates CRGB6 and CRGB42 of $P$. drechsleri collected from gerbera daisy at location B in 2002 collapsed into a unique haplotype (H7) with isolates NC88 and NC103 collected from gerbera daisy at the same location in 2007 (37). These isolates also had clone variants that grouped together in the ITS, $\beta$-tub, and $E F-1 \alpha$ genealogies. The grower reported having a yearly problem with Phytophthora root rot on gerbera daisy plants. Similarly, Lamour et al. (29) identified a clonal lineage of $P$. nicotianae that persisted in field-produced snapdragons from the 2000-01 growing season. In addition, Lamour et al. (29) identified infested verbena plants shipped between greenhouse facilities as the source of inoculum of $P$. nicotianae at two greenhouse facilities by developing amplified fragment length polymorphism profiles to identify clonal lineages of $P$. nicotianae. Developing additional information on genotypes of $P$. cryptogea and $P$. drechsleri present in the floriculture industry will be important for improving disease management strategies.

Considering all of the inferences together, it appears likely that divergence between $P$. cryptogea and $P$. drechsleri is recent and that speciation is still in progress for these species. This is in contrast to the study by Mostowfizadeh-Ghalamfarsa et al. (35), which found no evidence of gene flow and concluded that these were well-diverged species. The study by MostowfizadehGhalamfarsa et al. (35) did not resolve heterozygous sites within the analyzed DNA sequences. Cloning and determining alternate alleles for heterozygous sites in diploid organisms is needed for conducting the most robust analyses possible and was instrumental in detecting the recombination events and conflicts between the gene genealogies in the history of the isolates of $P$. cryptogea and $P$. drechsleri in our study. However, it is possible that our population of isolates has a unique history of recombination between these two species. The study by MostowfizadehGhalamfarsa et al. (35) used isolates of P. cryptogea and $P$. drechsleri from diverse hosts and origins, whereas the present study of these species used only isolates of these species from greenhouse floriculture crops. The greenhouse environment provides a unique opportunity for these two species to interact because $P$. cryptogea and $P$. drechsleri have overlapping floriculture host ranges. In addition, plant material is moved around the industry, providing a chance of introduction of both species to a single facility. In fact, $P$. cryptogea and $P$. drechsleri were found together in a block of gerbera daisies in a greenhouse in North Carolina (37). Additional studies with diverse isolates where alternate alleles are determined for heterozygous sites are needed to determine whether the recombination identified in our study has occurred in the evolutionary history of other isolates of $P$. cryptogea and $P$. drechsleri or is unique to isolates from this production system.

\section{ACKNOWLEDGMENTS}

Funding for this research comes, in part, from the Fred C. Gloeckner Foundation, Harrison, NY; the United States Department of AgricultureAgricultural Research Service Floriculture and Nursery Crops Research Initiative; and the North Carolina Agricultural Research Service, Raleigh. We thank M. Greene, K. L. Ivors, and K. C. Parker for technical assistance.

\section{LITERATURE CITED}

1. Aylor, D. L., Price, E. W., and Carbone, I. 2006. SNAP: Combine and map modules for multilocus population genetic analysis. Bioinformatics 22:1399-1401.

2. Bahlo, M., and Griffiths, R. C. 2000. Inference from gene trees in a subdivided population. Theor. Pop. Biol. 57:79-95.

3. Blair, J. E., Coffey, M. D., Park, S.-Y., Geiser, D. M., and Kang, S. 2008. A multi-locus phylogeny for Phytophthora utilizing markers derived from complete genome sequences. Fungal Genet. Biol. 45:266-277.

4. Bonants, P. J. M., Hagenaar-de Weerdt, M., Man in't Veld, W., and Baayen, R. P. 2000. Molecular characterization of natural hybrids of Phytophthora nicotianae and P. cactorum. Phytopathology 90:867-874.

5. Bowden, L. C., Price, E. W., and Carbone, I. 2008. SNAP Clade and Matrix, Version 2. Department of Plant Pathology, North Carolina State University. Online publication. http://www.cals.ncsu.edu/plantpath/ faculty/carbone/home.html.

6. Brasier, C. M., Cooke, D. E. L., and Duncan, J. M. 1999. Origin of a new Phytophthora pathogen through interspecific hybridization. Proc. Natl. Acad. Sci. USA 96:5878-5883.

7. Brasier, C. M., Kirk, S. A., Delcan, J., Cooke, D. E. L., Jung, T., and Man in't Veld, W. A. 2004. Phytophthora alni sp. nov. and its variants: Designation of emerging heteroploid hybrid pathogens spreading on Alnus trees. Mycol. Res. 108:1172-1184.

8. Bumbieris, M. 1979. Aspects of the biology of Phytophthora cryptogea. Aust. J. Bot. 27:11-16.

9. Cooke, D. E. L., Drenth, A., Duncan, J. M., Wagels, G., and Brasier, C. M. 2000. A molecular phylogeny of Phytophthora and related Oomycetes. Fungal Genet. Biol. 30:17-32.

10. Daughtrey, M. L., and Benson, D. M. 2005. Principles of plant health management for ornamental plants. Annu. Rev. Phytopathol. 43:141-169.

11. Ersek, T., and Nagy, Z. A. 2008. Species hybrids in the genus Phytophthora with emphasis on the alder pathogen Phytophthora alni: A review. Eur. J. Plant Pathol. 122:31-39.

12. Erwin, D. C., and Ribeiro, O. K. 1996. Phytophthora Diseases Worldwide. American Phytopathological Society, St. Paul, MN.

13. Farr, D. F., and Rossman, A. Y. Phytophthora cryptogea. Fungal Databases. Systematic Botany \& Mycology Laboratory, ARS, USDA. Online publication. http://nt.ars-grin.gov/fungaldatabases/.

14. Farr, D. F., and Rossman, A. Y. Phytophthora drechsleri. Fungal Databases. Systematic Mycology and Microbiology Laboratory, ARS, USDA. Online publication. http://nt.ars-grin.gov/fungaldatabases/.

15. Fu, Y. X. 1997. Statistical tests of neutrality of mutations against population growth. Genetics 147:915-925.

16. Fu, Y. X., and Li, W. H. 1993. Statistical tests of neutrality of mutations. Genetics 133:693-709.

17. Gerrettson-Cornell, L. 1979. Notes on the morphology of five isolates of Phytophthora cryptogea Pethyb. and Laff. from Australia. Phyton-Int. J. Exp. Bot. 37:105-118.

18. Goss, E. M., Carbone, I., and Grunwald, N. J. 2009. Ancient isolation and independent evolution of the three clonal lineages of the exotic sudden oak death pathogen Phytophthora ramorum. Mol. Ecol. 18:1161-1174.

19. Griffiths, R. C., and Tavare, S. 1994. Ancestral inference in population genetics. Stat. Sci. 9:307-319.

20. Hartl, D. L., and Clark, A. G. 2007. Principles of Population Genetics, 4th ed. Sinauer Associates, Inc., Sunderland, MA.

21. Hey, J., and Nielsen, R. 2004. Multilocus methods for estimating population sizes, migration rates, and divergence time with applications to the divergence of Drosophila pseudoobscura and D. persimilis. Genetics 167:747-760.

22. Ho, H. H., and Jong, S. C. 1986. A comparison between Phytophthora cryptogea and P. drechsleri. Mycotaxon 27:289-319.

23. Ho, H. H., and Jong, S. C. 1991. Species concepts of Phytophthora cryptogea and Phytophthora drechsleri. Mycotaxon 40:35-39.

24. Hudson, R. 2000. A new statistic for detecting genetic differentiation. Genetics 155:2011-2014.

25. Hudson, R., Boos, D. D., and Kaplan, N. L. 1992. A statistical test for detecting geographic subdivision. Mol. Biol. Evol. 9:138-151.

26. Hwang, J., and Benson, D. M. 2005. Identification, mefenoxam sensitivity, and compatibility type of Phytophthora spp. attacking floriculture 
crops in North Carolina. Plant Dis. 89:185-190.

27. Kang, S., Mansfield, M. A., Park, B., Geiser, D. M., Ivors, K., Coffey, M. D., Grunwald, N. J., Martin, F. N., Levesque, C. A., and Blair, J. E. 2010. The promise and pitfalls of sequence-based identification of plantpathogenic fungi and oomycetes. Phytopathology 100:732-737.

28. Kroon, L. P. N. M., Bakker, F. T., van den Bosch, G. B. M., Bonants, P. J. M., and Flier, W. G. 2004. Phylogenetic analysis of Phytophthora species based on mitochondrial and nuclear DNA sequences. Fungal Genet. Biol. 41:766-782.

29. Lamour, K. H., Daughtrey, M. L., Benson, D. M., Hwang, J., and Hausbeck, M. K. 2003. Etiology of Phytophthora drechsleri and $P$. nicotianae $(=P$. parasitica) diseases affecting floriculture crops. Plant Dis. 87:854-858.

30. Lyngs $\varnothing$, R. B., Song, Y. S., and Hein, J. 2005. Minimum recombination histories by branch and bound. Lect. Notes Bioinf. 3692:239-250.

31. Man in 't Veld, W., Veenbaas-Rijks, W. J., Ilieva, E., de Cock, A. W., Bonants, P. J. M., and Pieters, R. 1998. Natural hybrids of Phytophthora nicotianae and Phytophthora cactorum demonstrated by isozyme analysis and random amplified polymorphic DNA. Phytopathology 88:922-929.

32. Martin, F. N. 2000. Phylogenetic relationships among some Pythium species inferred from sequence analysis of the mitochondrially encoded cytochrome oxidase II gene. Mycologia 92:711-727.

33. Martin, F. N., and Tooley, P. W. 2003. Phylogenetic relationships among Phytophthora species inferred from sequence analysis of mitochondrially encoded cytochrome oxidase I and II genes. Mycologia 95:269-284.

34. Martin, F. N., Tooley, P. W., and Blomquist, C. L. 2004. Molecular detection of Phytophthora ramorum, the causal agent of sudden oak death in California, and two additional species commonly recovered from diseased plant material. Phytopathology 94:621-631.

35. Mostowfizadeh-Ghalamfarsa, R., Panabieres, F., Banihashemi, Z., and Cooke, D. E. L. 2010. Phylogenetic relationship of Phytophthora cryptogea Pethybr. \& Laff and P. drechsleri Tucker. Fungal Biol. 114:325-339.

36. Nielsen, R., and Wakeley, J. 2001. Distinguishing migration from isolation: A Markov Chain Monte Carlo approach. Genetics 158:885-896.
37. Olson, H. A., and Benson, D. M. 2011. Characterization of Phytophthora spp. on floriculture crops in North Carolina. Plant Dis. 95:1013-1020.

38. Ortiz-Barrientos, D., Reiland, J., Hey, J., and Noor, M. A. F. 2002. Recombination and the divergence of hybridizing species. Genetica 116:167-178.

39. Park, J., Park, B., Veeraraghavan, N., Jung, K., Lee, Y.-H., Blair, J. E., Geiser, D. M., Isard, F., Mansfield, M. A., Nikolaeva, E., Park, S.-Y., Russo, J., Kim, S. H., Greene, M., Ivors, K., Balci, Y., Peiman, M., Erwin, D. C., Coffey, M. D., Rossman, A. Y., Farr, D. F., Cline, E., Grunwald, N. J., Luster, D. G., Schrandt, J., Martin, F. N., Ribeiro, O. K., Makalowska, I., and Kang, S. 2008. Phytophthora Database: A forensic database supporting the identification and monitoring of Phytophthora. Plant Dis. 92:966-972.

40. Pethybridge, G. H., and Lafferty, H. A. 1919. A disease of tomato and other plants caused by a new species of Phytophthora. Sci. Proc. R. Dublin Soc. 15:487-505

41. Price, E. W., and Carbone, I. 2005. SNAP: Workbench management tool for evolutionary population genetic analysis. Bioinformatics 21:402-404.

42. Schena, L., and Cooke, D. E. L. 2006. Assessing the potential of regions of the nuclear and mitochondrial genome to develop a "molecular tool box" for the detection and characterization of Phytophthora species. J. Microbiol. Methods 67:70-85.

43. Tajima, F. 1989. The effect of change in population size on DNA polymorphism. Genetics 123:597-601.

44. Tompkins, C. M., Richards, B. L., Tucker, C. M., and Gardner, M. W. 1936. Phytophthora rot of sugar beet. J. Agric. Res. 52:205-216.

45. Tompkins, C. M., and Tucker, C. M. 1937. Foot rot of China-aster, annual stock, and Transvaal daisy caused by Phytophthora cryptogea. J. Agric. Res. 55:563.

46. Tompkins, C. M., Tucker, C. M., and Clarke, A. E. 1935. Root rot of Aster caused by Phytophthora cryptogea. (Abstr.) Phytopathology 25:895.

47. Tucker, C. M. 1931 (reprint 1967). The Taxonomy of the Genus Phytophthora de Bary. Wheldon \& Wesley, Ltd. and Stechert-Hafner Service Agency, Inc., New York. 